\title{
Utilization of Extract of Sambang Getih Leaves (Hemigraphis colorata. Hall. F) as a Acid-Base Indicator
}

\section{*Ekasari \& Purnama Ningsih}

Pendidikan Kimia/FKIP - Universitas Tadulako, Palu - Indonesia 94119

Received 05 December 2019, Revised 07 January 2019, Accepted 04 February 2020

doi: 10.22487/j24775185. 2020.v9.i1.pp7-15

\begin{abstract}
Getih sambang leaves (Hemigraphis Colorata. Hall. F) are plants that have a distinctive and unique color, namely the upper surface of the leaf is green and the bottom of the leaf is burgundy where sambang leaves contain anthocyanin compounds. Anthocyanin is the color pigment in plants that forms the basis of the use of natural indicators. This study aims to prove whether getih cucumber leaves can be used as an acid-base indicator, to determine the type of acid-base titration that is suitable for indicators of getih cucumber leaves, and to find out what the pH-changing color route of getih cucumber leaves is. The method used is extraction, namely maceration. Wee leaves are macerated by using methanol as a solvent for 24 hours. The extract was previously tested using $\mathrm{HCl}$ solution and $\mathrm{NaOH}$ solution as a test to prove the presence of anthocyanin. The results obtained in this study, getih sambang leaf extract can be used as an indicator of acid base, and also the type of acid-base titration that is suitable for use in the indicator of getih leaf extract extract precisely on the titration of strong-base strong acid, and strong weak base-acid It is best used as a substitute for the phenolphthalein indicator. In titration of strong and weak acids and bases, it is good to be used as a substitute for the indicator of methyl orange. The pH range obtained from the getih sambang leaf extract is pH 4-7 (red-purple).
\end{abstract}

Keywords: Getang cucumber, extract, indicator, acid-base

\section{Pendahuluan}

Indikator titrasi asam-basa adalah suatu senyawa organik yang dapat berubah warna dengan berubahnya $\mathrm{pH}$, bisa digunakan untuk membedakan suatu larutan bersifat asam atau basa dengan cara memberikan perubahan warna yang berbeda pada larutan asam dan basa. Indikator yang hanya digunakan dalam titrasi asam basa biasanya yang rentang $\mathrm{pH}$-nya sesuai dengan perubahan warna. Indikator $\mathrm{pH}$ biasanya asam lemah atau basa lemah yang berubah warna sesuai dengan $\mathrm{pH}$ larutan yang ditambahkan. Dengan indikator, kita dapat mengetahui tingkat kekuatan suatu asam atau basa (Lestari, 2016).

Indikator asam basa merupakan zat warna yang perubahan warnanya tampak jelas dalam rentang $\mathrm{pH}$ yang sempit. Kebanyakan dari laboratorium memakai indikator buatan atau bahan sintetis. Indikator yang sering digunakan dalam titrasi asam basa adalah indikator fenolftalein dan indikator metil merah (Gustriani dkk., 2016). Indikator sintetis tersebut sangat dibutuhkan ditingkat sekolah lanjutan sampai dengan perguruan tinggi. Selama ini indikator yang digunakan memiliki beberapa kelemahan seperti polusi kimia, ketersediaan dan biaya produksi tinggi. Indikator sintetis titrasi asam basa harganya relatif mahal dan sangat sulit didapatkan di daerah pedesaan (Nuryanti dkk., 2010). Selain itu, beberapan indikator sintetis ini memiliki efek toksik pada pengguna, serta menyebabkan pencemaran lingkungan (Daniel dkk., 2012).

Indikator alami dapat dibuat dengan dari berbagai tumbuhan berwarna yang ada di sekitar kita. Akan tetapi, tidak semua tumbuhan berwarna dapat memberikan perubahan warna yang jelas pada kondisi asam ataupun basa, oleh karena itu hanya beberapa saja yang dapat dipakai, misalnya tanaman dadap merah.

Penggunaan indikator alami umumnya hanya dilakukan dalam waktu yang singkat, mengingat kelemahannya yang tidak tahan lama (Usman dkk., 2017). Pada tanaman, warna disebabkan oleh adanya zat organik alami seperti flavon, flavonol, antosianin dan lain-lain (Pimvodkar dkk., 2014).

Antosianin termasuk golongan senyawa flavonoid, merupakan kelompok terbesar pigmen alami pada tumbuhan yang larut dalam air yang bertanggung jawab untuk memberikan warna pada bunga, buah dan sayuran (Lestari dkk., 2010). Pelarut yang baik untuk ekstraksi flavonoid khususnya antosianin yaitu etanol $70 \%$, karena memiliki sifat polar yang mampu melarutkan senyawa polar (Ratmasari dkk., 2016). Kestabilan

*Correspondence:

Ekasari

e-mail: ekasari.paransa026@gmail.com

(c) 2020 the Author(s) retain the copyright of this article. This article is published under the terms of the Creative Commons Attribution License 4.0, which permits unrestricted non-commercial use, distribution, and reproduction in any medium, provided the original work is properly cited. 
warna senyawa antosianin dipengaruhi oleh $\mathrm{pH}$ atau tingkat keasaman dan akan lebih stabil apabila dalam suasana asam atau $\mathrm{pH}$ yang rendah. Berdasarkan hal tersebut, tanaman yang mengandung antosianin dapat dijadikan sebagai indikator asam-basa (Hayati dkk., 2012).

Berdasarkan penelitian yang telah dilakukan oleh Agung (2017) bahwa tanaman sambang getih mengadung senyawa kimia antosianin dan antosianidin. Tanaman Sambang getih (Hemigraphis colorata Hall.F.) adalah tanaman yang berasal dari jawa dan merupakan salah satu jenis tanaman yang termasuk ke dalam suku Acanthaceae. Spesies ini memiliki nama daerah sebagai berikut, binalu api (Sumatera(Melayu)), remek daging, reundeu beureum (Sunda), keci beling, sambang geteh, sarap (Jawa), dan lire (Ternate). Tanaman sambang getih ini, bagian yang dapat dijadikan sebagai obat bagi kesehatan tubuh yaitu bagian daunnya saja. Berdasarkan penjelasan di atas, DSG bisa digunakan dan dijadikan sebagai indikator alami karena dalam daun ini terdapat kandungan senyawa kimia antosianin.

\section{Metode}

Alat yang digunakan dalam penelitian ini yaitu labu ukur, gunting, shaker, corong, aluminiumfoil, gelas kimia, pipet tetes, gelas ukur, tabung reaksi, rak tabung reaksi, penjepit tabung, buret, klem dan statif, erlenmeyer, neraca analitik, plat tetes, botol semprot, spatula, batang pengaduk, pipet volume, $\mathrm{pH}$ meter dan saringan teh.

Bahan yang digunakan dalam penelitian ini yaitu daun sambang getih, aquades, etanol $96 \%$, indikator fenolftalein (PP), $\mathrm{HCl}, \mathrm{NaOH}, \mathrm{NH}_{4} \mathrm{OH}$, $\mathrm{CH}_{3} \mathrm{COOH}, \mathrm{Na}_{2} \mathrm{CO}_{3}$, dan indikator orange (MO).

\section{Sampel Penelitian}

Sampel yang digunkan dalam penelitian ini adalah daun sambang getih (Hemigraphis colorata Hall.F.) yang diambil dari Desa Salumpaga, Kec.Toli-toli Utara, Kab.Tolitoli.

\section{Prosedur penelitian}

\section{Eksrtraksi Daun Sambang Getih}

10 gram daun sambang getih, dicuci dengan aquades sampai bersih, dipotong kecil-kecil kemudian dimasukkan kedalam erlenmeyer ditambah pelarut etanol sebanyak $100 \mathrm{~mL}$ shaker dan dimaserasi selama 24 jam. Ekstrak kemudian disaring menggunakan saringan teh. Hasil penyaringan siap digunakan sebagai indikator asambasa (Irwan dkk., 2017).

\section{Pembuatan Larutan dan Standarisasi Larutan}

\section{Pembuatan Larutan Natrium Karbonat $\left(\mathrm{Na}_{2} \mathrm{CO}_{3}\right)$} $0.1 M$

1,06 gram $\mathrm{Na}_{2} \mathrm{CO}_{3}$ secara kuantitatif, memasukkannya ke dalam labu ukur $100 \mathrm{~mL}$, melarutkannya dengan aquades sampai garis tanda batas pada labu takar (Pratama, 2013).
Pembuatan Larutan Asam Klorida (HCl) $0.1 \mathrm{M}$

2,07 $\mathrm{mL}$ larutan $\mathrm{HCl}$ ke dalam labu ukur $250 \mathrm{~mL}$ kemudian mengencerkannya dengan aquades hingga garis tanda batas pada labu takar (Pratama, 2013).

\section{Standarisasi Larutan $\mathrm{HCl}$ oleh $\mathrm{Na}_{2} \mathrm{CO}_{3}$}

$20 \mathrm{~mL}$ larutan $\mathrm{Na}_{2} \mathrm{CO}_{3}$ 0,1 $\mathrm{M}$ dengan menggunakan pipet tetes dan menuangkannya ke dalam gelas ukur, menuangkan ke dalam erlenmeyer $100 \mathrm{~mL}$, menambahkan 3 tetes indikator metil jingga. Memasukkan larutan $\mathrm{HCl}$ ke dalam buret. Menitrasi $\mathrm{Na}_{2} \mathrm{CO}_{3}$ tersebut dengan larutan $\mathrm{HCl}$ yang sudah disiapkan sampai titik akhir titrasi (terjadi perubahan warna). Mencatat volume $\mathrm{HCl}$ dan mengulangi titrasi sebanyak 3 kali (Pratama, 2013).

\section{Pembuatan Larutan Natriun Hidroksida (NaOH) $0.1 M$}

1 gram $\mathrm{NaOH}$ secara kuantitatif, memasukkannya ke dalam labu ukur $250 \mathrm{~mL}$, melarutkannya dengan aquades sampai garis tanda batas pada labu takar (Pratama, 2013).

\section{Standarisasi Larutan $\mathrm{NaOH}$ oleh $\mathrm{HCl}$}

Menyiapkan larutan standar $\mathrm{HCl} 0,1 \mathrm{M}$. Mengambil $20 \mathrm{~mL}$ larutan $\mathrm{HCl} 0.1 \mathrm{M}$ dengan pipet tetes dan menuangkannya ke dalam gelas ukur, menuangkan ke dalam erlenmeyer $100 \mathrm{~mL}$, menambahkan 3 tetes indikator penolftalein. Memasukkan larutan $\mathrm{NaOH}$ ke dalam buret. Menitrasi $\mathrm{HCl}$ tersebut dengan larutan $\mathrm{NaOH}$ yang sudah disiapkan sampai titik akhir titrasi (terjadi perubahan warna). Mencatat volume $\mathrm{NaOH}$ dan mengula ngi titrasi sebanyak 3 kali (Pratama, 2013).

\section{Pembuatan Larutan Asam Asetat $\left(\mathrm{CH}_{3} \mathrm{COOH}\right) 0.1$ $M$}

$0,41 \mathrm{~mL}$ larutan $\mathrm{CH}_{3} \mathrm{COOH}(1 \mathrm{~L}=1.05$ $\mathrm{kg}, \mathrm{M}=60.05 \mathrm{~g} / \mathrm{mol}$ ) kedalam labu takar $250 \mathrm{~mL}$. Kemudian mengencerkannya dengan aquades sampai garis tanda batas pada labu takar (Pratama, 2013).

\section{Standarisasi Larutan $\mathrm{CH}_{3} \mathrm{COOH}$ Oleh $\mathrm{NaOH}$}

$20 \mathrm{~mL}$ larutan $\mathrm{CH}_{3} \mathrm{COOH} \mathrm{0,1} \mathrm{M} \mathrm{dengan}$ pipet tetes dan menuangkannya ke dalam gelas ukur, menuangkan ke dalam erlenmeyer $100 \mathrm{~mL}$, menambahkan 3 tetes indikator fenolftalein. Memasukkan larutan $\mathrm{NaOH}$ ke dalam buret. Menitrasi $\mathrm{CH}_{3} \mathrm{COOH}$ tersebut dengan larutan $\mathrm{NaOH}$ yang sudah disiapkan sampai titik akhir titrasi (terjadi perubahan warna). Mencatat volume $\mathrm{NaOH}$ dan mengulangi titrasi sebanyak 3 kali (Pratama, 2013).

\section{Pembuatan Larutan Amonium Hidroksida $\left(\mathrm{NH}_{4} \mathrm{OH}\right) 0.1 \mathrm{M}$ \\ $3.85 \mathrm{~mL} \mathrm{NH}_{4} \mathrm{OH} 25 \%,(1 \mathrm{~L}=0.91 \mathrm{~kg}) \mathrm{ke}$ dalam labu ukur 250 mL. Kemudian mengencerkannya dengan akuades sampai garis tanda batas pada labu takar (Pratama, 2013).}




\section{Standarisasi Larutan $\mathrm{NH}_{4} \mathrm{OH}$ oleh $\mathrm{HCl}$}

$20 \mathrm{~mL}$ larutan $\mathrm{NH}_{4} \mathrm{OH} \quad 0.1 \mathrm{M}$ dengan pipet tetes dan menuangkannya ke dalam gelas ukur, menuangkan ke dalam erlenmeyer $100 \mathrm{~mL}$, menambahkan 3 tetes indikator metil orange. Memasukkan larutan $\mathrm{HCl}$ ke dalam buret.
Menitrasi $\mathrm{NH}_{4} \mathrm{OH}$ tersebut dengan larutan $\mathrm{HCl}$ yang sudah disiapkan sampai titik akhir titrasi (terjadi perubahan warna). Mencatat volume $\mathrm{HCl}$ dan mengulangi titrasi sebanyak 3 kali (Pratama, 2013).

\section{Uji Pembuktian Antosianin secara Kualitatif}

Tabel 1. Uji pembuktian senyawa antosianin

\begin{tabular}{cll}
\hline No & \multicolumn{1}{c}{ Perlakuan } & \multicolumn{1}{c}{ Karateristik Antosianin } \\
\hline 1. & Dipanaskan dengan $\mathrm{HCl} 2 \mathrm{M}$ selama \pm 5 menit pada & Warna merah tidak pudar \\
suhu $100^{\circ} \mathrm{C}$ & Warnah merah berubah warna menjadi hijau, biru
\end{tabular}
dan memudar perlahan-lahan.

\section{Pengujian Warna pada Larutan Asam dan Basa}

Ekstrak daun sambang getih yang diperoleh diuji dengan diteteskan sebanyak tiga tetes kedalam larutan $\mathrm{HCl} 0.1, \mathrm{NaOH} 0.1, \mathrm{NH}_{4} \mathrm{OH}$ 0.1, $\mathrm{CH}_{3} \mathrm{COOH} 0.1 \mathrm{M}$, kemudian diamati perubahan warnanya (Irwan dkk., 2017).

\section{Pengujian Warna dengan Larutan Buffer}

Larutan dimasukkan kedalam tabung sempurnah dengan $\mathrm{pH}$ yang berbeda-beda yaitu $\mathrm{pH}$ 1 sampai $\mathrm{pH}$ 12. Kemudian ditambahkan dengan ekstrak daun sambang getih sebanyak 3 tetes kedalam masing-masing larutan buffer. Selanjutnya mencatat perubahan warna yang terjadi (Nuryanti, dkk., 2010).

\section{Pengujian pada Titrasi Asam Basa}

\section{Titrasi Asam Kuat-Basa Kuat}

$20 \mathrm{~mL}$ larutan $\mathrm{HCl} \quad 0.1 \mathrm{M}$, lalu dimasukkan ke dalam erlenmeyer, kemudian ditambahkan 3 tetes ektrak daun sambang getih dan dititrasi dengan $\mathrm{NaOH} 0.1 \mathrm{M}$, hingga terjadi perubahan warna. Titrasi dilakukan sebanyak 3 kali. Dicatat volume titer yang digunakan. setiap $2 \mathrm{~mL}$ titer yang digunakan diukur nilai $\mathrm{pH}$-nya hingga terjadi perubahan warna. Selanjutnya mengulangi titrasi dengan menggunakan indikator penolftalein untuk pembanding (Irwan dkk., 2017).

\section{Titrasi Asam Lemah - Basa Kuat}

$20 \mathrm{~mL}$ larutan $\mathrm{CH}_{3} \mathrm{COOH} 0.1 \mathrm{M}$, lalu dimasukkan kedalam erlenmeyer. Ditambahkan 3 tetes ektrak daun sambang getih dan dititrasi dengan $\mathrm{NaOH} 0.1 \mathrm{M}$, hingga terjadi perubahan warna. Titrasi dilakukan sebanyak 3 kali. Dicatat volume titer yang digunakan. setiap $2 \mathrm{~mL}$ titer yang digunakan diukur nilai $\mathrm{pH}$-nya hingga terjadi perubahan warna. Selanjutnya mengulangi titrasi dengan menggunakan indikator penolftalein untuk pembanding (Irwan, 2017).

\section{Hasil dan Pembahasan}

\section{Ekstraksi Daun Sambang Getih}

Ekstraksi DSG pada penelitian ini menggunakan metode maserasi, yang mana maserasi ini adalah proses perendaman sampel untuk menarik komponen yang diinginkan dengan kondisi dingin diskontinyu (Putra, 2014). Pemilihan metode ini didasarkan pada sifat kelarutan dari komponen di dalam pelarut (Siregar \& Nurlela, 2011). Maserasi dilakukan dengan menggunakan $100 \mathrm{~mL}$ metanol selama 24 jam. Sampel tersebut kemudian disaring menggunakan saringan teh untuk memisahkan residu dan filtratnya, dan filtrat tersebut merupakan hasil ektrak dari DSG. Pemilihan penggunaan saringan teh untuk memisahkan residu dan filtrat dari eksrak DSG agar supaya warna yang dihasilkan tidak terserap seperti halnya menyaring menggunakan kertas kasa. Kemudian penggunaan metanol sebagai pelarut didasarkan pada sifat metanol yang polar yang akan melarutkan senyawa antosianin. Penetapan waktu maserasi selama 24 jam berdasarkan penelitian Siregar \& Nurlela (2011) yang melakukan variasi waktu maserasi terhadap pigmen antosianin bunga kembang sepatu.

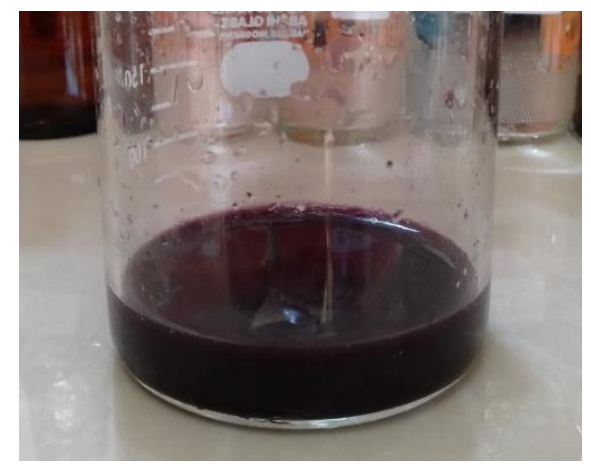

Gambar 1. Ekstrak daun sambang getih 
Berdasarkan isolasi senyawa flavonoid dari ekstrak etanol daun sambang getih yang dilakukan oleh Agung (2017) dapat diketahui bahwa dari hasil isolasi tersebut, esktrak daun sambang getih mengandung senyawa antosianin dan antosianidin. Hal tersebut dapat menjadi indikasi bahwa di dalam daun sambang getih terdapat pigmen antosianin, yang mana antosianin ini merupakan pigmen yang berperan dalam memberikan warna pada bunga, buah dan daun pada tumbuhan.

\section{Uji Pembuktian Senyawa Antosianin}

Identifikasi senyawa antosianin ini bertujuan untuk menguji ada tidaknya kandungan senyawa antosianin dari suatu tanaman. Pengujian ini dilakukan dengan cara mengambil sampel yang telah diekstrak dan ditetesi $\mathrm{NaOH} 2 \mathrm{M}$ sedikit demi sedikit sampai terjadi perubahan warna, perubahan warna tersebut yang menunjukkan uji positif dari adanya antosianin dalam sampel tersebut disajikan dalam Tabel 2.

Tabel 2. Uji pembuktian senyawa antosianin

\begin{tabular}{ccc}
\hline Sampel & Perlakuan & Karakteristik Antosianin \\
\hline Ekstrak daun sambung getih & Dipanaskan dengan HCL 2 M selama \pm 5 & Warna merah tidak pudar \\
& menit pada suhu $100^{\circ} \mathrm{C}$ & Warnah merah berubah warna menjadi \\
& Ditambahkan $\mathrm{NaOH} 2 \mathrm{M}$ tetes demi tetes & hijau \\
\hline
\end{tabular}

\section{Pengujian Warna Indikator DSG pada Larutan Asam-Basa}

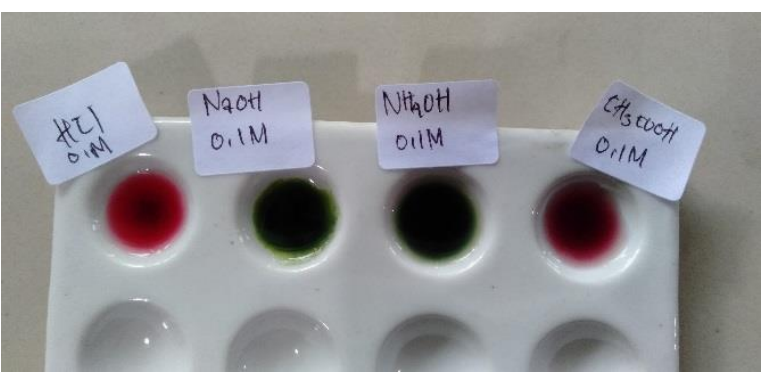

Gambar 2. Warna ekstrak dsg pada larutan asam - basa

Berdasarkan gambar diketahui bahwa, indikator ekstrak daun sambang getih yang menggunakan pelarut asam dan basa memberikan perubahan warna. Larutan asam yang digunakan yaitu untuk larutan $\mathrm{HCl}$ yang menunjukkan perubahan warna ungu kehitaman berubah wrana menjadi warna merah muda, untuk larutan $\mathrm{CH}_{3} \mathrm{COOH}$ yang menunjukkan warna ungu kehitaman berubah warna menjadi warna merah dan larutan basa yang digunakan yaitu untuk larutan $\mathrm{NaOH}$ yang menunjukkan perubahan warna ungu kehitaman berubah warna menjadi hijau, untuk larutan $\mathrm{NH}_{4} \mathrm{OH}$ menunjukkan perubahan warna ungu kehitaman berubah warna menjadi warna hijau tua. Kemampuan berubah

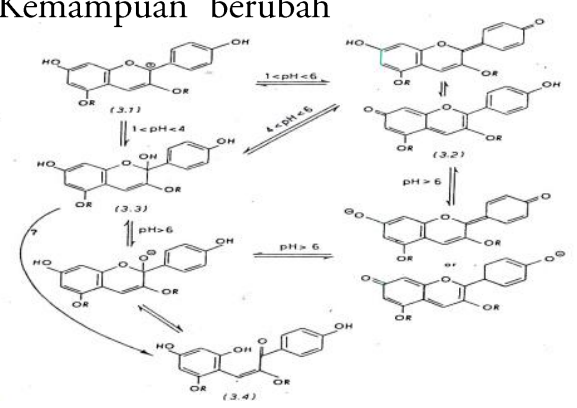

Gambar 3. Bentuk kesetimbangan kation flavilium pada antosianin dalam berbagai rentang $\mathrm{pH}$

Pengujian pada Larutan Buffer pH 1 - 12

Larutan buffer merupakan larutan dari asam lemah dan basa konjugatnya atau basa lemah dan asam konjugatnya. Sifat utama larutan buffer adalah daya tahannya terhadap perubahan $\mathrm{pH}$ warna yang terjadi pada ekstrak daun sambang getih pada kondisi asam dan basa tersebut disebabkan karena adanya antosoianin yang didalam strukturnya mengandung kation flavilium, yang dapat berubah bentuk strukturnya oleh pengaruh $\mathrm{pH}$. Apabila $\mathrm{pH}$ dinaikkan $(\mathrm{pH}<4)$ akan terbentuk karbinolbase tidak berwarna dan selanjutnya akan terjadi kesetimbangan toutometri membentuk kalkon. Pada kondisi pH > 6 mengalami perubahan bentuk struktur menjadi anhidrobase yang dapat terjadi perluasan ikatan delokal, sehingga menebabkan perubahan warna yang lebih kuat intensitasnya dan menghasilkan warna biru (Nuryanti, dkk., 2010). akibat penambahan sejumlah kecil asam kuat atau basa kuat (Frantauansyah dkk., 2013). 


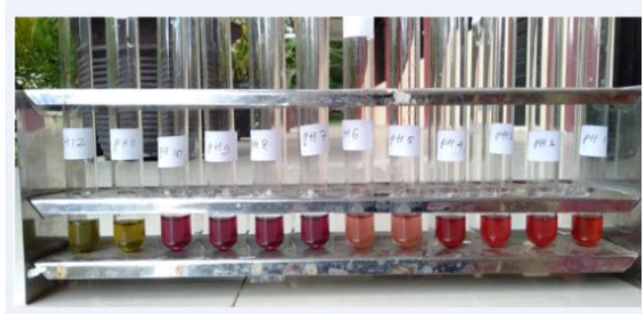

Gambar 4. Warna ekstrak DSG pada larutan buffer $\mathrm{pH} 1-12$

Berdasarkan hasil yang diperoleh dapat menjadi indikasi untuk mengetahui trayek $\mathrm{pH}$ dari warna di dalam berbagai rentang $\mathrm{pH}$ disebabkan dalam ekstrak daun sambaing getih mengandung ekstrak daun sambaing getih. Terjadinya perubahan antosianin (Frantauansyah dkk., 2013).

Tabel 3. Hasil pengujian warna indicator ekstrak DSG dalam larutan bufer

\begin{tabular}{cc}
\hline Larutan Buffer & Warna Larutan Ekstrak DSG \\
\hline pH 1 & Merah \\
pH 2 & Merah \\
pH 3 & Merah \\
pH 4 & Merah \\
pH 5 & Merah Muda \\
pH 6 & Merah Muda \\
pH 7 & Ungu \\
pH 8 & Ungu \\
pH 9 & Ungu \\
pH 10 & Ungu \\
pH 1 & Hijau \\
pH 12 & Hijau \\
\hline
\end{tabular}

Hasil yang diperoleh ini dapat menjadi indikasi untuk mengetahui trayek $\mathrm{pH}$ dari ekstrak daun sambang getih. Oleh karna kemampuan mata untuk membedakan warna-warni sangat terbatas, maka trayek $\mathrm{pH}$ suatu indikator dapat ditentukan mengguanakan alat yang mampu membedakan panjang warna-warni dari indikator (Nuryanti, dkk., 2017).

Berdasarkan hal di atas, maka ekstrak DSG dapat digunakan sebagai indikator alami didasarkan oleh adanya perubahan warna pada setiap perubahan $\mathrm{pH}$. Terjadinya perubahan warna di dalam berbagai rentang $\mathrm{pH}$ disebabkan oleh kandungan utama zat warna pada daun sambang getih berupa senyawa antosianin. Antosianin lebih stabil dalam media asam pada $\mathrm{pH}$ rendah dari pada dalam larutan alkali dengan $\mathrm{pH}$ tinggi (Rein, 2005).

\section{Pengujian pada Titrasi Asam - Basa (Asam Kuat- Basa Kuat)}

Berdasarkan hasil pengamatan, pada penggunaan indikator daun sambang getih titik ekivalen tercapai pada penambahan volume 19.7 $\mathrm{mL}$ larutan $\mathrm{NaOH}$ dengan $\mathrm{pH}$ rata-ratanya 8.75 serta perubahan warna yang terjadi dari warna merah muda berubah warna menjadi warna hijau kekuningan. Sedangkan untuk indikator pembanding yang digunakan yaitu indikator fenolftalein, titik ekivalen tercapai pada penambahan volume $19.3 \mathrm{~mL}$ larutan $\mathrm{NaOH}$ dengan $\mathrm{pH}$ rata-ratanya yaitu 8.46 dan perubahan warna yang terjadi yaitu dari tidak berwarna menjadi warna ungu muda. Secara teori rentang $\mathrm{pH}$ perubahan indikator fenolftalein berada pada kisaran 8.0 - 10.0 (Irwan, 2014). Dari data tersebut rentang $\mathrm{pH}$ perubahan ekstrak DSG sebagai indikator berada pada rentang $\mathrm{pH}$ perubahan indikator fenolftalein. Sehingga ekstrak DSG baik untuk digunakan sebagai indicator titrasi asam kuat-basa kuat, karena rentang $\mathrm{pH}$ perubahan warna ekstrak DSG masih berada pada range perubahan $\mathrm{pH}$ indikator fenoftalein disajikan pada Gambar 5.

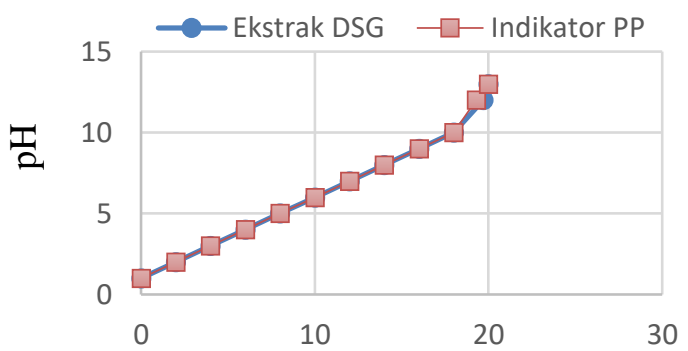

Gambar 5. Kurva perbandingan titrasi asam kuat basa kuat dengan menggunakan indikator DSG dan PP

Kurva titrasi asam kuat-basa kuat yang menggunakan indikator ekstrak daun sambang getih dengan indikator pembanding fenolftalein menunjukkan niali $\mathrm{pH}$ yang tidak jauh berbeda. Berdasarkan kurva tersebut, nilai $\mathrm{pH}$ dari kedua indikator pada penambahan $0 \mathrm{~mL}$ sampai 
penambahan $20 \mathrm{~mL} \mathrm{NaOH} 0.1 \mathrm{M}$ cenderung berimpitan. Hal tersebut mengindikasikan bahwa indikator ekstrak daun sambang getih dapat digunakan sebagai indikator titrasi asam kuat-basa kuat.

\section{Pengujian pada Titrasi Asam - Basa (Asam Lemah - Basa Kuat)}

Berdasarkan hasil pengamatan tersebut pada penggunaan indikator daun sambang getih titik ekivalen tercapai pada penambahan volume $18.3 \mathrm{~mL}$ dengan $\mathrm{pH}$ rata-ratanya 8.41 serta perubahan warna yang terjadi dari warna merah muda berubah warna menjadi warna hijau kekuningan (hampir tak berwarna). Sedangkan untuk indikator pembading yang digunakan yaitu indikator fenolftalein, titik ekivalen tercapai pada penambahan volume $18.4 \mathrm{~mL}$ dengan $\mathrm{pH}$ rataratanya yaitu 8.41 dan perubahan warna yang terjadi yaitu dari tidak berwarna menjadi warna ungu muda. Secara teori rentang $\mathrm{pH}$ perubahan indikator fenolftalein berada pada kisaran $8.0-10.0$ (Irwan, 2014). Dari data tersebut rentang $\mathrm{pH}$ perubahan ekstrak DSG sebagai indikator berada pada rentang $\mathrm{pH}$ perubahan indikator fenolftalein. Sehingga ekstrak DSG baik untuk digunakan sebagai indikator titrasi asam lemah - basa kuat, karena rentang $\mathrm{pH}$ perubahan warna ekstrak DSG masih berada pada range perubahan $\mathrm{pH}$ indikator fenoftalein disajikan pada Gambar 6.

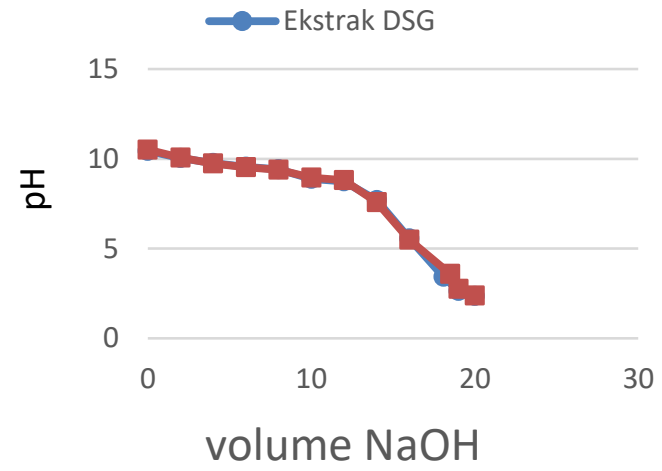

Gambar 6. Kurva perbandingan titrasi asam lemah-basa kuat dengan menggunakan indikator DSG dan $\mathrm{PP}$

Kurva titrasi asam lemah-basa kuat yang menggunakan indikator ekstrak daun sambang getih dengan indikator pembanding fenolftalein menunjukkan niali $\mathrm{pH}$ yang tidak jauh berbeda. Berdasarkan kurva tersebut, nilai $\mathrm{pH}$ dari kedua indikator pada penambahan $0 \mathrm{~mL}$ sampai penambahan $20 \mathrm{~mL} \mathrm{NaOH} 0,1 \mathrm{M}$ cenderung berimpitan. Hal tersebut mengindikasikan bahwa indikator ekstrak daun sambang getih dapat digunakan sebagai indikator titrasi asam lemah-basa kuat.

\section{Pengujian pada Titrasi Asam - Basa (Basa Lemaht - Asam Kuat)}

Berdasarkan hasil pengamatan tersebut pada penggunaan indikator daun sambang getih titik ekivalen tercapai pada penambahan volume $18.1 \mathrm{~mL}$ denga $\mathrm{pH}$ rata-ratanya 3.43 serta perubahan warna yang terjadi dari warna hijau berubah warna menjadi warna merah muda. Sedangkan untuk indikator pembanding yang digunakan yaitu indikator metil orange, titik ekivalen tercapai pada penambahan volume 18.5 $\mathrm{mL}$ dengan $\mathrm{pH}$ rata-ratanya yaitu 3.59 dan perubahan warna yang terjadi yaitu dari warna orange berubah warna menjadi warna merah. Secara teori rentang $\mathrm{pH}$ perubahan indikator metil orange berada pada kisaran 3.0 - 4.0 (Irwan, 2014). Dari data tersebut rentang $\mathrm{pH}$ perubahan ekstrak DSG sebagai indikator berada pada rentang $\mathrm{pH}$ perubahan indikator metil orange. Sehingga ekstrak DSG baik untuk digunakan sebagai indikator titrasi basa lemah - asam kuat, karena rentang $\mathrm{pH}$ perubahan warna ekstrak DSG masih berada pada range perubahan $\mathrm{pH}$ indikator metil orange disajikan pada Gambar 7.

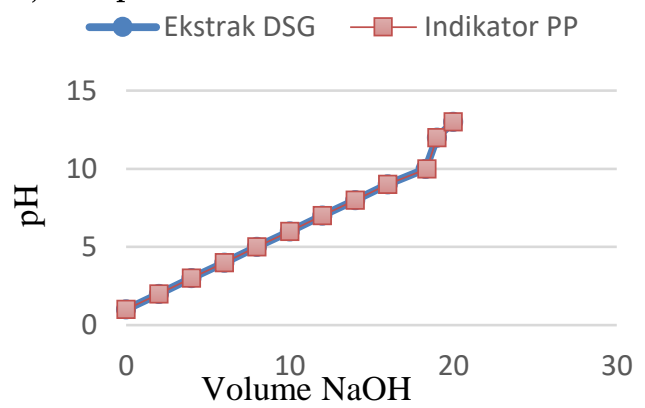

Gambar 7. Kurva perbandingan titrasi basa lemahasam kuat dengan menggunakan indikator DSG dan PP

Kurva titrasi basa lemah-asam kuat yang menggunakan indikator ekstrak daun sambang getih dengan indikator pembanding metal orange menunjukkan niali $\mathrm{pH}$ yang tidak jauh berbeda. Berdasarkan kurva tersebut, nilai $\mathrm{pH}$ dari kedua indikator pada penambahan $0 \mathrm{~mL}$ sampai penambahan $20 \mathrm{~mL} \mathrm{HCl} 0.1 \mathrm{M}$ cenderung berimpitan. Hal tersebut mengindikasikan bahwa indikator ekstrak daun sambang getih dapat 
digunakan sebagai indikator titrasi asam lemah-basa kuat.

Ketiga kurva yang dihasilkan dari pengujian pada titrasi asam-basa, kurva yang ditunjukkan dari titrasi asam lemah-basa kuat memiliki hasil yang lebih baik, berdasarkan hasil pengamatan, $\mathrm{pH}$ yang dihasilkan berubah agak cepat pada awal penambahan $\mathrm{NaOH}$ dan kemudian naik sedikit demi sedikit sampai mendekati titik ekivalen. Kenaikan tersebut dikarenakan terbentuknya larutan penyangga (Buffer) akibat dari penambahan larutan yang bersifat basa kuat. Sifat dari penyangga ini akan mempertahankan $\mathrm{pH}$ sampai jumlah basa yang ditambahkan berlebihan (Day \& Underwood, 2002).
Senyawa organik yang dapat digunakan sebagai indikator titrasi asam-basa adalah senyawa organik yang dapat berubah warna dengan berubahnya $\mathrm{pH}$. Senyawa ini paling sering dijumpai sebagai indikator titik akhir titrasi. Dua indikator yang khas adalah metil orange dan fenolftalein. Metil orange berwarna merah dalam larutan asam dengan $\mathrm{pH}$ kurang dari 3.1 dan dalam larutan basa berwarna kuning dengan $\mathrm{pH}$ di atas 4.4. Sebaliknya fenolftalein berubah warna pada $\mathrm{pH}$ di atas 7 , sampai $\mathrm{pH} 8.3$ fenolftalein tidak berwarna. Pada $\mathrm{pH}$ 10 zat ini berwarna merah (Fessenden \& Fessenden, 1986). Bentuk kesetimbanagan dari indikator fenolftalein dapat dilihat pada gambar 8 .
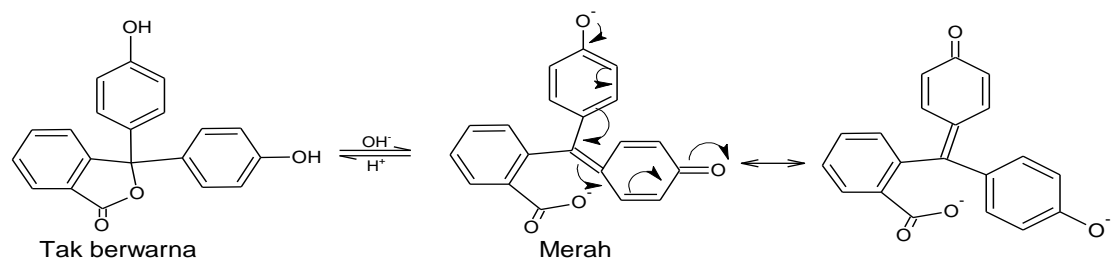

Gambar 8. Bentuk Kesetimbangan Fenolftalein (Nuryanti dkk.,2010).

Indikator metil orange banyak digunakan dalam titrasi asam kuat-basa lemah yang merupakan suatu basa berwarna kuning, dengan penambahan muda. Bentuk kesetimbangan dari indikator metil orange dapat dilihat pada Gambar 9. ion hidrogen menghasilkan kation berwarna merah

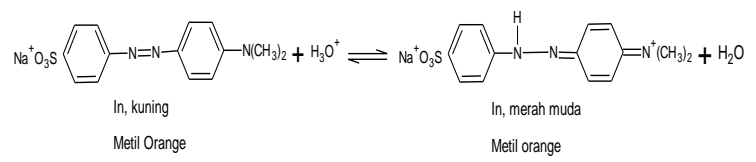

Gambar 9. Bentuk Kesetimbangan Indikator Metil Orange (Nuryanti, dkk., 2010)

\section{Kesimpulan}

Ekstrak daun sambang getih dapat digunakan sebagai indikator asam-basa. Jenis titrasi asam-basa yang cocok pada penggunaan indikator ekstrak daun wungu tepatnya pada titrasi asam kuat-basa kuat, dan asam lemah- basa kuat baik digunkan untuk pengganti indikator fenolftalein sedangkan pada titrasi basa lemah-asam kuat baik digunakan sebagai pengganti indikator metil orange. Trayek $\mathrm{pH}$ yang diperoleh pada ekstrak DSG yaitu pH 4-7 (Merah - Ungu).

\section{Ucapan Terima kasih}

Ucapan terima kasih penulis berikan kepada laboran Laboratorium Kimia FKIP, dan seluruh pihak yang telah membantu penulis dalam menyelesaikan penelitian ini.

\section{Referensi}

Afandy, M. A., Nuryanti, S., \& Diah, A. W. M. (2017). Ekstrak ubi jalar ungu (ipomea batatas. 1) menggunakan variasi pelarut serta pemanfaatannya sebagai indikator asam basa. Jurnal Akademika Kimia, 6(2), 79-85.

Agung, W. R. (2017). Isolasi senyawa flavonoid dari ekstrak etanol daun sambang getih (Hemigraphis alternata (Burm.F). Skripsi Tidak Diterbitkan. Bandung: Universitas Al-Ghifari.

Daniel, A. A., Ohene, B., Apea \& Pritchett, G. (2012). Investigation of a simple and cheap source of a natural indicator for acid-base titration: effects of system conditions on natural indicators. Green and Sustainable Chemistry Journal, 2(3), 117-122.

Day, R. A., \& Underwood, A. L. (2002). Analisis kimia kualitatif. Jakarta: Erlangga.

Fessenden, R. J., \& Fessenden, J. S. (1986). Kimia organik jilid 2 edisi ketiga. Jakarta: Erlangga.

Frantauansyah, Nuryanti, S., \& Hamzah, B. (2013). Ekstrak bunga waru (Hibicus tiliaceus) sebagai indikator asam basa. Jurnal Akademika Kimia, 2(1), 11-16. 
Gustriani. N, Novitriani. K., \& Mardiana. U, (2016). Penentuan trayek pH ekstrak kubis ungu (Brssica oleracea L) sebagai indikator asam basa dengan variasi konsentrasi pelarut etanol. Jurnal Kesehatan Bakti Tunas Husada, 16(1), 94-100.

Hayati, E. K., Budi, U. S., \& Hermawan. R. (2012). Konsentrasi total senyawa antosianin ekstrak kelopak bunga rosella (Hibicus sabdariffa L). Jurnal Kimia, 6(2), 138-147.

Indira, C., (2015). Pembuatan indikator asam basa karaunting. Kaunia, 11(1), 1-10.

Irwan, (2014). Identifikasi flavonoid pada ekstrak bunga kembang merak (Caesalpinia pulcherrima). Skripsi Tidak Diterbitkan. Palu: Universitas Tadulako.

Irwan. (2017). Ekstrak daun wungu (Graptophyllum pictum(L) griff) sebagai indikator asam basa. Skripsi Tidak Diterbitkan. Palu: Universitas Tadulako.

Lestari, P. (2016). Kertas indikator bunga belimbing wuluh (Averrhoa bilimbi L) untuk uji larutan asam basa. Jurnal Pendidikan Madrasah, 1(1), 69-83.

Lestari, S., Suzery, M. \& Cahyono, B. (2010). Penetuan total antosianin dari kelopak bunga rosella (Hibicus Sabdariffa. L) dengan metode maserasi dan sokshletasi. Jurnal Sains dan Matematika, 18(1), 1-6.

Lestario, L. N., Rahayuni. E., \& Timotius, K. H. (2011). Kandungan antosianin dan identifikasi antosianidin dari kulit buah jenitri (Elaeocarpus angustifolius Blume). Agritech, 31(2), 93-101.

Nuryanti, S., Matsjeh, S., Anwar, C., \& Raharjo, T, J. (2010). Indikator titrasi asam-basa dari ekstrak bunga sepatu (Hibicus rosa sinensis L). Agritech, 30(3), 178-183.

Pimvodkar, N. V., Surve, B. S., \& Bhise, S. H. (2014). Use of argyreia cuneata flower extract as a natural indicator in acid base. Journal of Current Pharma Research, 4(2), 1124-1127.

Pratama, Y. (2013). Pemanfaatan ekstrak daun jati (Tectona grandis linn. F) sebagai indikator asam basa. Skipsi Tidak Diterbitkan, Malang: Universitas Negeri Malang.

Putra, A. A. B., Bogoriani, N. W., Diantariani, N. P., \& Sumadewi, N. L. U, (2014). Ekstraksi zat warna alam dari bonggol tanaman pisang (Musa paradisiaca L.) dengan metode maserasi, refluks dan sokhletasi. Jurnal Kimia, 8(1), 113-119.

Praadap, D. J., \& Dave, K. (2013). A novel, inex pensive and less hazardous acid-base indicator. Journal of Chemical Edication, 1(2), 34-38.

Rahmawati, Nuryanti, S., \& Ratman. (2016). Indikator asam basa dari bunga dadap merah (Erythtrina crista-galli. L). Jurnal Akademika Kimia, 5(1), 29-36.

Ratmasari, S., Subendar, D., \& Amalia, V. (2016). Studi potensi ekstrak daun adam hawa (Rhoe discolor) sebagai indikator titrasi asam basa. Chimica et Natura Acta, 4(1), 39-46.

Rein. M, (2005). Conpigmentation Reactions and Color Stability of Berry Anthocyanins. Unpublished doctoral disertation, Helnski: University of Helsinki.

Siregar, Y. D. I., \& Nurlela, (2011). Ekstraksi dan uji stabilitas zat warna alami dari bunga kembang sepatu (hibiscus sabdarifa). Jurnal Valensi, 2(3), 459-467.

Usman, Sukemi, Putra, B. I., Purwati, W., Rahmawati, N. N., \& Pradani, (2017). Indikator asam basa dari ekstrak etanol pucuk daun pucuk merah (Syzygium oelana). Jurnal Kimia dan Pendidikan Kimia, 2(3), 139-144. 